\title{
An Analysis on Indonesian English Translation Shifts Found in Two Short Stories of Bilingual Children Book Series Published by "Gema Insani"
}

\author{
Mabruroh \\ English Educational Department, Faculty of Language and Art, PGRI \\ University Banyuwangi
}

$\begin{array}{ll}\text { Received } & \text { : Monday, September 17, } 2018 \\ \text { Revised } & \text { : Monday, September 24, } 2018 \\ \text { Accepted } & \text { : Friday, September 28, 2018 }\end{array}$

Abstract

English is international language which everyone should understand even a little. In this research, the researcher deals about translation shift especially in the bilingual children books. Indonesian is the source language while English as the target language. The objective of this research are to find out kinds of translations shift and to know how are the translation shift applied in translating two of short stories there are "Cerita Si Lebah and Cerita Si kupu-kupu". This book very interesting, many children like to read this book, because this book makes children easy to learn English. In book Cerita Si Lebah and Si Kupu-Kupu translating Indonesian into English there are a shifting. Shift is departures from formal correspondence in the process of going from SL into the TL. There are two types Translation shift they are Level Shift and Category Shift.

The method of this research uses descriptive qualitative method. The data analysis used by the researcher is content analysis. The researcher read and compares both Indonesian as the source language and English as the target language. The researcher took the entire sentence from the Indonesian text and English text, check whether there are shifts in translations which are taken the valid data. Then, analyze the types of translation shifts occurred and draw conclusion based on the analysis.

The objects being analyzed are books entitle Cerita Si Lebah and Cerita $\mathrm{Si}$ Kupu-Kupu. The researcher takes the data from that's book found 22 data there are 1 data is Level Shift and 21 data is category shift. Then, from Cerita si Lebah was found 9 data, they are level shift and category shift. The category shifts found are unit shift, structure shift and class shift. From Cerita Si Kupu-Kupu book found 13 data they are category shift, they are structure shift and Intra system shift. So, it can be concluded that the translation shift found in two short are mostly category shift.

Keywords:Translation, Translation Shifts, Short Stories

\section{A. Introduction}

Language is very important communication tool. English language is an example for the importance of a language because it is the international language and has become the most important language for people in many parts of the world. There are many reasons that makes English is the most important language in the world, one of them is English mostly used in publishing books, making film, music and a lot of 
entertainment things. There are so many languages in this world, we need a translation to make understand and it easier for us in communication. In term of translation, we have been acquainted with both the source language (SL) text and the target language (TL) text. Source language $(S L)$ is the language being translated, while Target language (TL) is the language being translated. To be a good translator, not only translating the meaning from the SL into the $\mathrm{TL}$, but also delivering the authentic message.

The main problem in translation is the different of grammar system of SL and TL. SL grammar of a text is replaced by equivalent formal corresponding TL grammar, there will be no shift. But translation equivalence from formal correspondencein SL grammar may not exist in the TL grammar, it lends to the shift. Catford (1965:73) cited in Selly Anna Ringga Sari (2013:1) defines shift as "departures from formal correspondence in the process of going from SL to the TL". Shifting in translation unlikely to be avoided because of cultural differences and sentence structure in every language available, thus requiring theoretical understanding in the translation process. Catford (1965:73) cited in Selly Anna Ringga Sari (2013:1) defined there are two types of translation shift "Level Shift and Category Shift". The Catagory shifts there are four "Class Shift, Structure Shift, Unit Shift and Intra System Shift".

\section{B. Problem of the Research}

What types of translation shift found in two short stories of Bilingual Children Book series published by Gema Insani?

How are the translation shift applied in two short stories of Bilingual Children Book series published by Gema Insani from Indonesian into English?

\section{Objective of the Research}

Based on the problem of the research, the objectives of the research are:

To analyze types of translation shift found in two short stories of bilingual children they are Cerita Si Lebah and Cerita Si Kupu-Kupu published by Gema Insani.

To analyze how the translation are shift applied in two short stories of Bilingual Children Book series published by Gema Insani from Indonesian into English

\section{Significance of the Research}

The result of the research was expected to give benefits, for children, the research and other researchers and the readers:

\section{For children}

This research can facilitate the children to make easier for understand reading English Story.

\section{For research and other researchers}

This research can increase the knowledge about translation shift for the research, and it can used as a references or alternative source for other researcher. 


\section{For the Reader}

This research help the readers to know which word include the types of translation shift available in the books.

This research give knows to the readers How are the translation shift applied in the books.

This research can help the reader easily to understand the reading books.

\section{E. Research Methodology}

In this research, the researcher used descriptive qualitative method. According to (Moleong, 2009:3) descriptive research was a type of a research which result the descriptive data in the form of written or oral words from observed object. The process of research involves emerging questions and procedures, data typically collected in the participant's setting, data analysis inductively building from particulars to general themes, and the researcher making interpretation of the meaning of the data. This research uses descriptive qualitative, because the data is not analyzed by statistical procedure, the data were in the form of words and this study was case study which focused on the short stories book, which was to be the object of the research. In this research the researcher used by content analysis to collect the data, classifying the data, analyzes them and drawing conclusion without making any generalization.

In doing analysis, the researcher compared the studies of some previous researchers which the same case as this research. There are:

a. Took the entire sentence from the Indonesian text and English text

b. Check whether there are shifts in translations which are taken the valid data.

c. Analyze the types of translation shifts occurred.

d. Draw conclusion based on the analysis

\section{F. Result}

The result is found by describing the translation shift used by the researcher. All types of translation shift are found in the data. There are 22 data that found by the researcher. 1 categorized level shift and 21 data is categorized shift. Then, from Cerita si Lebah was found 9 data, they are level shift and category shift. The category shifts found are unit shift, structure shift and class shift. From Cerita Si Kupu-Kupu book found 13 data they are category shift, they are structure shift and Intra system shift. Therefore, the translation result can be categorized as a "good" translation.

\section{G. Discussion}

After analyzing the selected data, the researcher found all types of translation, there are level shift and category shift. According to the data finding the researcher is going to discuss how translation shift usually happen. Those shifts occur within grammar level so that, Catford call it as level and category shift.

Level shift meant by Catford here is the shift from the level grammar to lexis and vice versa. It means that level here is structuring dimension of language is based on the subtance of phonic, graphic and 
situations. The researcher found one level shift as change from grammar to lexis. There are four of category shift:

The first is unit shift. Unit shift involves changes in rank. The translation equivalent of a unit shift to one rank in SL is the unit at a different rank in TL. The researcher found 3 unit shifts such as change from clause to word, phrase to clause, and phase to compound word

The second is structure shift. Structure shift usually occur in the agreement of sentence, a clause, or a phrase the researcher found two structure shifts that is noun followed by adjective.

The third is class shift. Class shift occur when the translation equivalent of SL item is a member of a different class from the original item. The researcher found one class shift change the adjective to noun.

The fourth is intra system shift. Intra system shift occurs when SL and TL process system which approximately correspond formally as to their constitution but translation involves selection of a non-corresponding term in the TL system. The article and number system are regarded as formally corresponding in English and Indonesian. The researcher found 4 intra system shift such as one number shift from singular to plural noun, article shift from plural, and the last from article to number system

\section{H. Acknowledgement}

Our sincere gratitude is hereby extended to the following people who never ceased in helping until this research is structured: Abdul Munir, M.Pd, as the Dean of Language and Art of Faculty PGRI University of Banyuwangi. Wulan Wangi, M.Pd, as the Head of English Education Department PGRI University of Banyuwangi and also my first consultant. Arin Inayah, S.S, M.Pd, as my second Consultant

\section{Reference}

Alzuhdy, Yosa Abduh. 2014. "Jurnal Ilmiah Bahasa, Sastra dan Pengajaranya".

http://journal.uny.ac.id/index.php/diksi/article/vie w/3188. accessed [11 April 2017]

Baker, Mona. 1998. Routledge Encyclopedia of Translation Studies. London and New York: Routledge. Cited in Siti Muhtalifah. 2011 Bell, Roger T. 1993. Translation and Translating: Theory and Practice. London: Longman Group UK. Cited in Siti Muhtalifah. 2011

Catford, J. C. 1965. A Linguistic Theory of Translation. London: Oxford University Press. Cited in Putri Nafisah Diena. 2015

Chesterman, Andrew. 2000. Memes of Translation the Spread of Ideas in Translation Theory. Amsterdam/Philadelphia: John Benjamins Publishing Company. Cited in Yosa Abduh Alzuhdy. 2014

Dewi Pisca Ardiyanthi S.Ar. 2010. The Intrinsic Elements of the House By Dina Oktaviani. Unplushed. Jakarta: faculty of abad and humanities state Islamic University of Syarif Hidayatulloh. 
Farkhan, Muhammad. Proposal Penelitian Bahasa dan Santra. Jakarta: Abadia Pres. 2011.

Haryani, Jumi. Cerita Si Lebah. (Jumi Haryani. Terj) Depok: Gema Insani. 2010.

Haryani, Jumi. Cerita Si Kupu-Kupu. (Jumi Haryani. Terj) Depok: Gema Insani. 2016.

Herman. "Category Shift in the English Translation of Harry Potter and the Philosopher 's Stone Movie Subtille i nto Indonesia (An Aplied Linguistics Study)." IOSR Journal of Humanities and Social Science, vol.19. No.5.Dec:2014: 31-38Larson, Mildred. Meaning Based Translation. A Guide to Cross-Language Equivalence. Maryland: University Press of America. 1984. Cited in Selly Anna Ringga. 2013

Muhtalifah,Siti. 2011. An Analysis of English-Indonesian Translation Shift in the Hanna Banana Short Story By Ribut Wahyudi. Unpublised. Jakarta: faculty of abad and humanities state Islamic University of Syarif Hidayatulloh.

Newmark, Peter. 1981. Approaches to Translation. Oxford: Pergamon Press. Cited in Siti Muhtalifah. 2011.

Nida, E. A and C. Taber. The Theory and Practice of Transaltion. Leiden: E. J.Brill. 1969. Cited in Hariyanto sugeng Zuchridin. 2003..

Hariyanto sugeng, Zuchridin. 2003. Translation, Bahasa Teori dan Penuntun Practktis Menerjemahkan. Yogyakarta.

Semingson,Peggy PhD. 2015. European Scientific Journal February edition vol.3 ISSN: n1857-7881.. (17) Diena, Putri Nafisah. 2015. EnglishIndonesian Category Shift in the Srawberry Shortcake Bilingual Children Book. Unpublised. Jakarta: faculty of abad and humanities state Islamic University of Syarif Hidayatulloh 